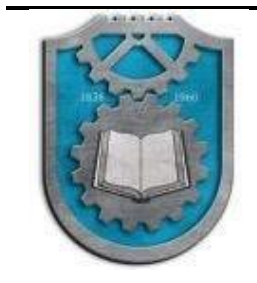

MOBILITY \& VEHICLE MECHANICS

DOI: $10.24874 / \mathrm{mvm} .2021 .47 .03 .04$

UDC: 62833.6

\title{
HYBRID POWER TRAINS FOR HIGH-SPEED TRACKED VEHICLES
}

\author{
Luka Ponorac $^{1 *}$, Aleksandar Grkic ${ }^{2}$, Slavko Muždeka $^{3}$
}

Received in July 2020

Revised in September 2020

Accepted in February 2021

RESEARCH ARTICLE

\begin{abstract}
Unlike independent steering systems on wheeled vehicles, the steering mechanism on high-speed tracked vehicles are integrated in the power train system, therefore turning process consumes more engine power than straight driving scenario. To ensure the most efficient turning performance, power trains of high speed tracked vehicles are equipped with complex turning mechanism components which are, most frequently, mechanical or hydrostatic. In most cases mechanical components enable turning process by slipping of the clutches and other frictional components, which is inconvenient from the aspect of power balance, as well as from the performance aspect. On the other hand, hydrostatic components have low efficiency in certain working ranges. Modernization of the conventional mechanical systems by applying electric drive components can contribute to solving the mentioned downsides, given the fact that modern electric drive systems can have very sensitive torque and speed regulation which significantly improves electric drive performance. Applying these electric drives in auxiliary power flow ensures additional flexibility and the possibility for the power train to work in different working regimes, such as energy regeneration, which improves the power train efficiency. This paper includes a variety of possible hybrid power trains for high-speed tracked combat vehicles and a fully developed simulation model of a hybrid drive for power trains with two power flows (main and auxiliary). The simulation model provides the possibility to observe the quantified influence of the certain parameter change in the turning process and allows us to identify the important parameters for power train control during the turning process.
\end{abstract}

KEY WORDS: hybrid power train, high-speed tracked vehicles, turning mechanisms, power train simulation model

(C) 2021 Published by University of Kragujevac, Faculty of Engineering

\footnotetext{
${ }^{1}$ Luka Ponorac, M.Sc.ME, inspection engineer, ADR laboratory, AMSS Motor Vehicle Centre Ltd, 58

Kneginje Zorke, 11000 Belgrade, Serbia, luka.ponorac@cmv.rs (*Corresponding author)

${ }^{2}$ Aleksandar Grkić, Head of ADR and ATP laboratories, AMSS Motor Vehicle Centre Ltd, 58

Kneginje Zorke, 11000 Belgrade, Serbia, aleksandargrkic@cmv.rs

${ }^{3}$ Slavko Muždeka, Assoc. prof., University of Defence in Belgrade, Military Academy, 33 Generala

Pavla Jurišića Šturma Str., 11000 Belgrade, Serbia, slavko.muzdeka@gmail.com
} 


\section{HIBRIDNI SISTEM POGONA ZA BRZOHODA GUSENIČNA VOZILA}

REZIME: Za razliku od nezavisnih sistema upravljanja na vozilima na točkovima, upravljački mehanizam na brzohodim guseničnim vozilima je integrisan u sistem pogona, pa proces zaokretanja vozila zahteva više snage od motora nego kod pravolinijske vožnje. Da bi se obezbedile najefikasnije performanse zaokretanja, pogonski sklopovi brzih vozila sa gusenicama opremljeni su složenim komponentama mehanizma za zaokretanje koje su najčešće mehaničke ili hidrostatičke. U većini slučajeva mehaničke komponente omogućavaju proces zaokretanja klizanjem spojnice i drugih frikcionih komponenata, što je nezgodno sa aspekta bilansa snage, kao i sa aspekta performansi. S druge strane, hidrostatičke komponente imaju nisku efikasnost u određenim radnim režimima. Modernizacija konvencionalnih mehaničkih sistema primenom komponenti električnog pogona može doprineti rešavanju pomenutih nedostataka, s obzirom na činjenicu da savremeni sistemi sa električnim pogonom mogu imati veoma osetljivu regulaciju obrtnog momenta i brzine koja značajno poboljšava performanse električnog pogona. Primena ovih električnih pogona u pomoćnom toku snage osigurava dodatnu fleksibilnost i mogućnost rada pogonskog sklopa u različitim režimima rada, poput regeneracije energije, što poboljšava efikasnost pogona. Ovaj rad uključuje niz mogućih hibridnih pogona za brza borbena vozila na gusenicama i potpuno razvijen simulacioni model hibridnog pogona za pogone sa dva toka snage (glavni i pomoćni). Simulacioni model pruža mogućnost posmatranja kvantifikovanog uticaja određene promene parametara u procesu okretanja i omogućava nam da identifikujemo važne parametre za upravljanje pogonom tokom procesa okretanja.

KLJUČNE REČI: hibridni pogon, brzohoda gusenična vozila, mehanizam zaokretanja, simulacioni model pogona 


\title{
HYBRID POWER TRAINS FOR HIGH-SPEED TRACKED VEHICLES
}

\author{
Luka Ponorac, Aleksandar Grkić, Slavko Muždeka
}

\section{INTRODUCTION}

Since the development of electric motors as hybrid drives on commercial vehicles, there have been several attempts of applying the same technology on high-speed tracked vehicles, most commonly for military uses. The majority of these attempts are oriented on using electric motors as drive machines combined with IC engines. There are applications with parallel power flow [1], serial power flow [2], electric motors directly on drive wheels [3] etc. All of these solutions include using electric motors as drive machines and placing them in the main power flow, mainly to improve driving performances. On the other hand, these modernizations require electric motors with extremely high torque and power, as well as specific batteries and following electric systems which are usually very expensive. Modernization of the existing turning system integrated into the power train system presented in this paper represents a unique solution for manoeuvrability improvement. Applying electric motors in auxiliary drive, as turning mechanisms, provides significant improvement of turning parameters and potentially gives additional capabilities, while using non-expensive and relatively low power electric motors. Also, the capability to use electric motors as the source of drive power is maintained.

\section{TURNING MECHANISM}

Turning process of high-speed tracked vehicles is much more complex than wheeled vehicle turning process. Unlike with wheeled vehicle steering systems, tracked vehicles require significantly more engine power/torque for turning, than for linear movement. This is because of the high levels of force that resists the turning of the vehicle, which are not present during linear movement, or are present on a much lower level. Figure 1 shows the simplified mechanical model of the tracked vehicle during the turning process [4].

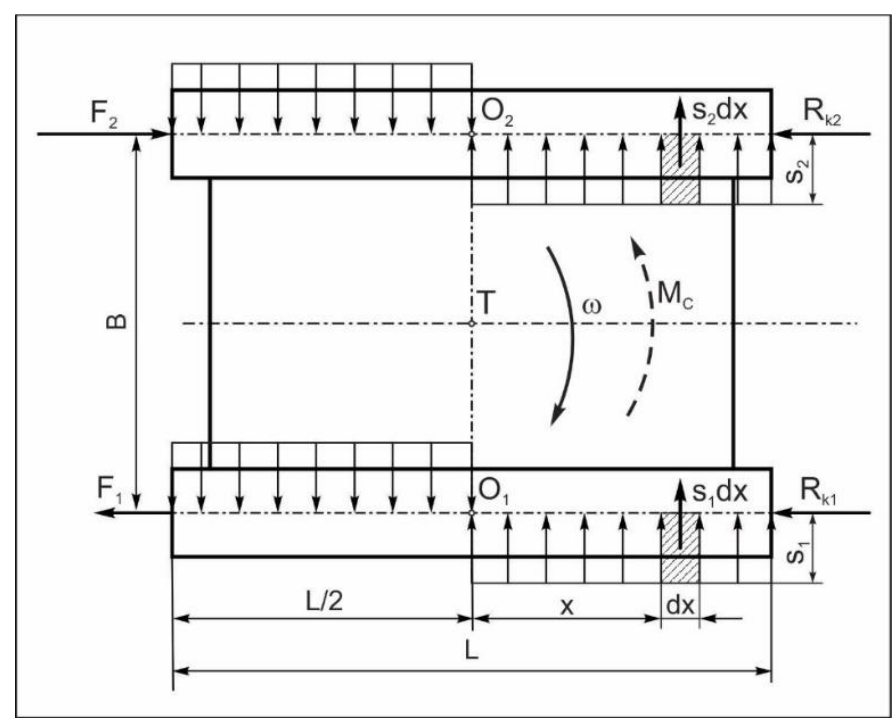

Figure 1 Resisting forces during the turning process 
where:

- $\quad R_{k 1}, R_{k 2}[\mathrm{~N}]$ - lienear movement ressistance

- $\quad s_{1}, s_{2}[\mathrm{Nm}]$-specific ressistance to transversal track movement

$F_{1}, F_{2}[\mathrm{~N}]$-braking force on the inner/drive force on the outer track.

Turning mechanisms on tracked vehicles provide the rotational speed difference between left and right drive wheel, that is, winding speed difference between inner and outer track, thus enabling the tracked vehicle to make a turn. The main parameter that describes the turning process is turning radius. As mentioned, turning process is achieved by enabling the winding speed difference of the tracks, which means that the turning radius is defined by the translational speed of the inner and outer track. This relation comes from the kinematic analyses of the tracked vehicle turning process and is described by the following equation:

$$
R=\frac{B}{2} \cdot \frac{V_{2}+V_{1}}{V_{2}-V},
$$

where:

- $\quad B$-track width

- $\quad V_{2}, V_{1}$-translational velocities of outer and inner track

Generally, there are two types of turning mechanisms applied in high-speed tracked vehicle:

- $\quad$ Symmetrical/differential

- Asymmetrical.

During the turning process, the symmetrical turning mechanism allows the vehicle mass centre to keep the velocity that it had during the linear movement. Most commonly, the outer track gains velocity for the same value that the inner track velocity is reduced, comparing to mass centre. This allows the vehicle the advantage of pivot turn, around its own vertical axis. The downside of these turning mechanisms is their construction complexity; most commonly combined with hydrostatic and additional mechanical components ("zero" shaft). During the turning process, the asymmetrical turning mechanism ensures that one point on the vehicle, usually the outer track, keeps the velocity of the linear movement, while the velocity of the mass centre and inner track is reduced.

\section{BVP M80A POWER TRAIN CONSTRUCTION}

The power train analysed in this paper is the power train of the infantry fighting vehicle BVP M80A, with an asymmetrical turning mechanism. It is a mechanical, integrated power train, with parallel main and auxiliary power flow. The main power flow is achieved through the mechanical gearbox (labelled as MP, Figure 2) and joins with the auxiliary power flow in the turning mechanism, that is, in the planetary gear set. Vehicle power train scheme is shown in Figure 2. 


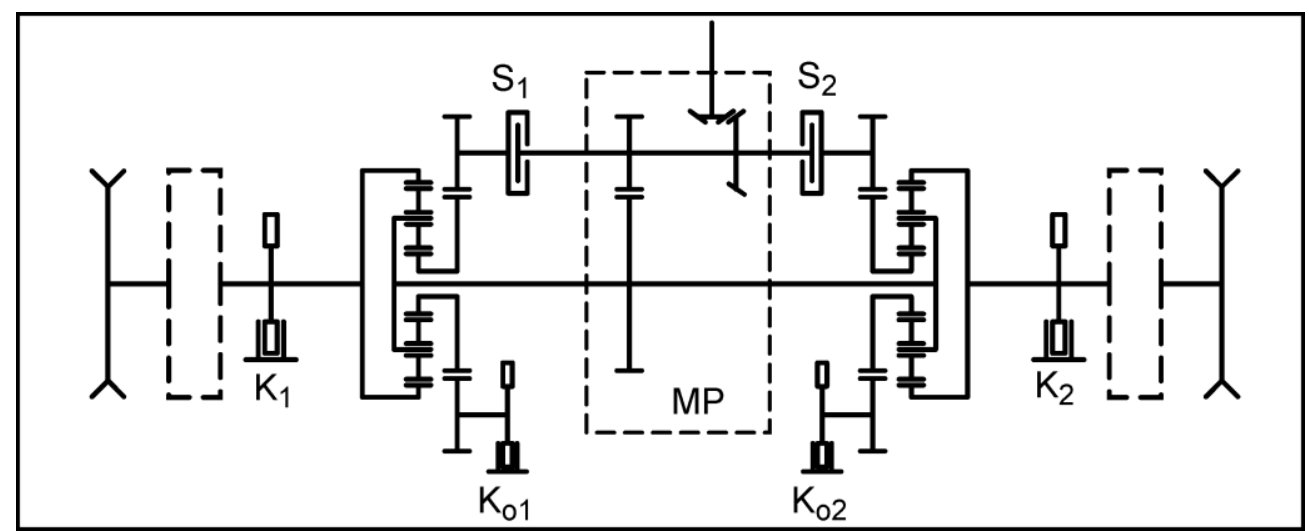

Figure 2 Turning mechanism scheme

The angular velocity on both planet carriers, which are connected to the gearbox output shaft, are the same. The difference in angular velocity on ring gears, thus on drive wheels, is achieved with sun gears, which are connected to the auxiliary power flow. During the linear movement, the sun gears are braked by brakes and. When the turning process starts one of the mentioned brakes is disengaged, while the engagement of clutch or gradually starts. When one of the clutches is engaged, the corresponding sun gear speeds up, thus reducing the angular velocity of the ring gear and the drive wheel. The described turning mechanism achieves the requested turning radius by slipping of the friction elements for all turning radii except for those when the friction elements are fully engaged. When the friction elements of the turning mechanism are fully engaged, the turning radii achieved in these states are called calculated turning radii, and for this type of turning mechanism, there are two turning.

The first one is achieved when the clutch $\left(S_{1}\right.$ or $\left.S_{2}\right)$ on the inner track sun gear is engaged, while the sun gear on the other side is braked.

The second calculated radius is achieved when the power train output shaft/drive wheel is braked with brakes $K_{1}$ or $K_{2}$, so the vehicle turns around the inner track.

There is a specific state where none of the friction elements on the inner track part of the power train are engaged, so there is neither drive nor braking force on the inner track, thus allowing the track to wind freely.

Worn surfaces of the shoe sleeve were measured in two planes and two mutually perpendicular sections. The location of the planes: A - A - $15 \mathrm{~mm}$ from the end face of the sleeve B - B -. $10 \mathrm{~mm}$ from the flange of the sleeve. The measurement scheme is shown in Figure 3.

$D$ - bushing outer diameter; $d$ - bushing inner diameter; $d_{l}$ - diameter of inner worn surface; $L$ - amount of wear.

The measurement of the inner diameter is carried out using the indicator caliper IC 10 GOST 868 - 82 with a division value of $0.01 \mathrm{~mm}$ (Figure 4). 


\section{PROPOSED MODERNIZATION}

The previously described turning system has many drawbacks. Having the defined number of turning radii can be a downside, especially because not all of them can be achieved in every driving condition. Because of the abrupt changes of the turning states, it is common that the driver makes a mistake and doesn't anticipate the turning conditions, which can lead to the track falling of the drive wheel, vehicle instability and similar inconveniences. One of the possible solutions for overcoming the stated problems is applying electric motors in the auxiliary drive, instead of clutches and (Figure 2). This means that the auxiliary drive power would no longer be drawn from the IC engine, but from the electric motors instead, making the auxiliary drive independent. Figures $3 \mathrm{a}$ and $3 \mathrm{~b}$ show the potential placement of the electric motors (EM) in the auxiliary drive.

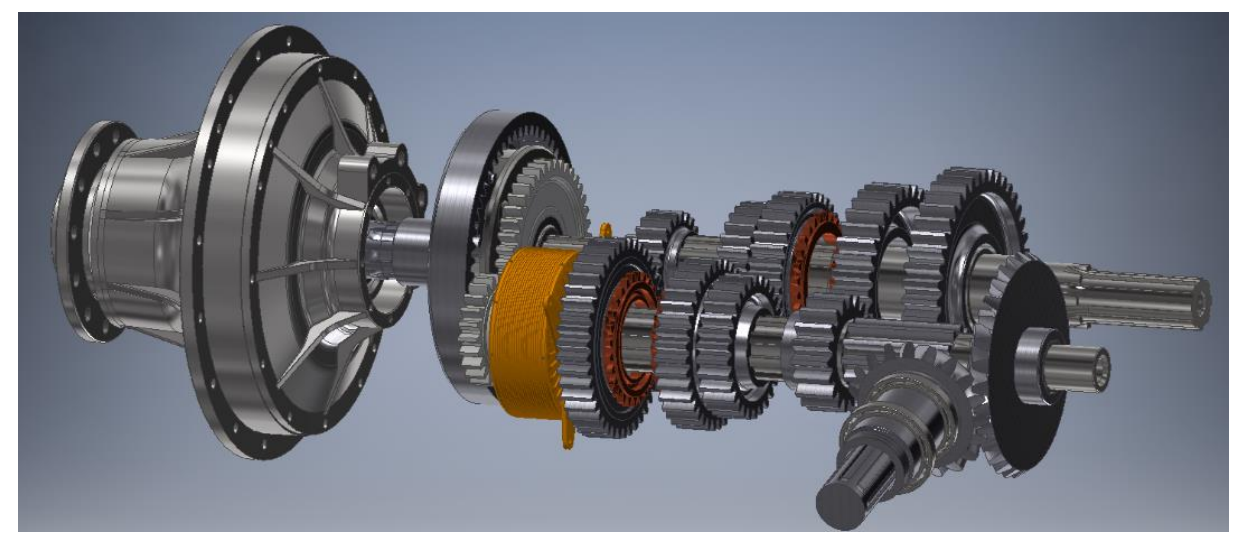

Figure 3 a Electric motor in auxiliary drive (power train left cross section)

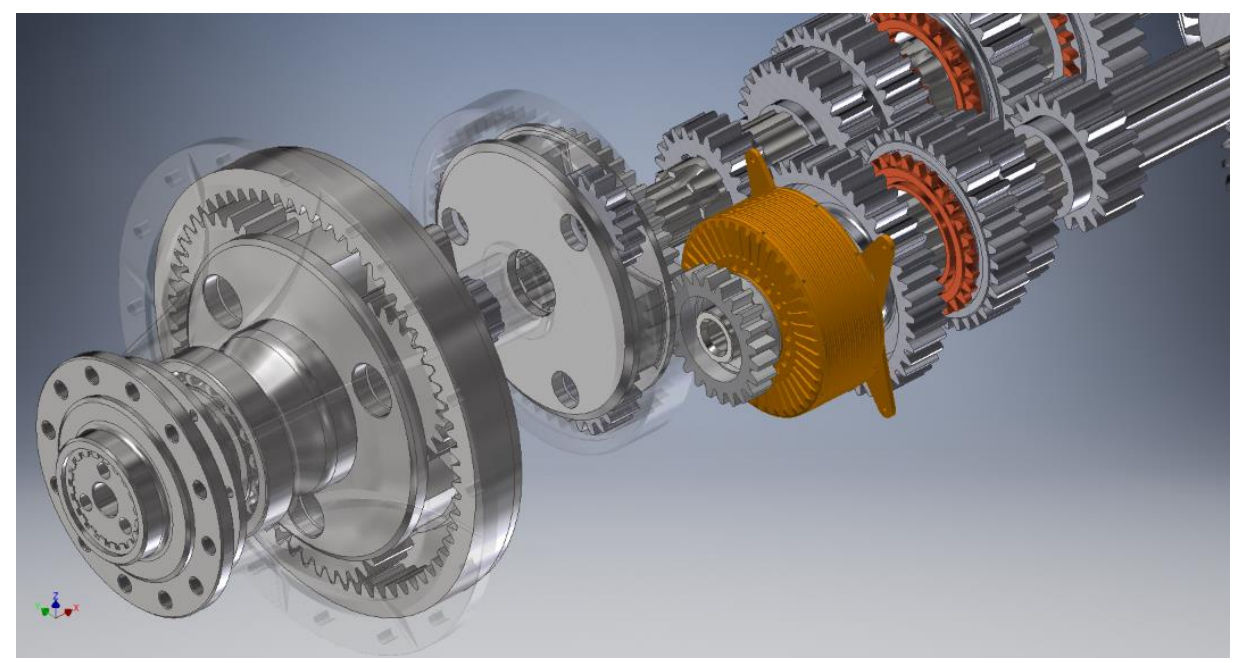

Figure $3 b$ Electric motor in auxiliary drive (power train left cross section

Precise speed control of the electric motors would result with achieving the wanted sun gear angular speed, thus being able to control the speed of the inner track. As a result, in a certain range, there would potentially be an infinite number of turning radii, and the turning process would be smoother. Applying electric motors in the auxiliary drive eliminates the losses of 
the turning mechanism friction components, and the torque characteristic of the electric engine, which is maximum at motor start, is compatible to the requirements of the turning dynamics. One of the important improvements of this conception is that it allows the power train and turning mechanisms to act as both symmetric and asymmetric. If the electric motor of the outer track is braked, and the one on the inner brake is working, the turning mechanisms will act as asymmetric. On the other hand, if the electric motor of the inner track is reducing its speed for a certain value, and the other motor enables the speed increase of the outer track for the same value, the turning mechanisms would act as symmetric. As a result, the vehicle would be able to make a pivot turn. There are other perks of applying electric motors in the auxiliary drive such as driving only on electric power, generating power in certain turning states etc. When it comes to cost and energy effectiveness, the electric auxiliary drive could potentially be carried out with minimum expenses and reconstruction of the existing power train. If synchronous electric motors were applied on the subject vehicle, instead of the previously described turning mechanism clutches, they need not have the power greater than $P=50 \mathrm{~kW}$ and angular velocity not greater than $n=2000 \mathrm{rpm}$. As for the batteries and power grid, the system works on nominal voltage of $U=460 \mathrm{~V}$ and amperage of $I=200 \mathrm{~A}$.

\section{SIMULATION MODEL}

For the purpose of comparative analyses of turning mechanism performance, simulation models were developed for both existing mechanical and proposed hybrid power train. The simulation models allow us to run kinematic and dynamic analyses for both power trains and acquire data needed for comparative analyses, such as track velocity, torque, turning radius, engine load, as well as to determine required parameters for the hybrid power train auxiliary drive. Since the difference between the existing and proposed power train is in the auxiliary drive, the existing power train simulation model will be described fully, while only describing the difference of the hybrid power train simulation model. The BVP M80A simulation model consists of three subsystems/groups of mechanical components (Figure 4):

- IC engine with main friction clutch

- Integrated power train subsystem

- Track subsystem.

Other than these mechanical component groups, there are:

- Control signals

- Results. 


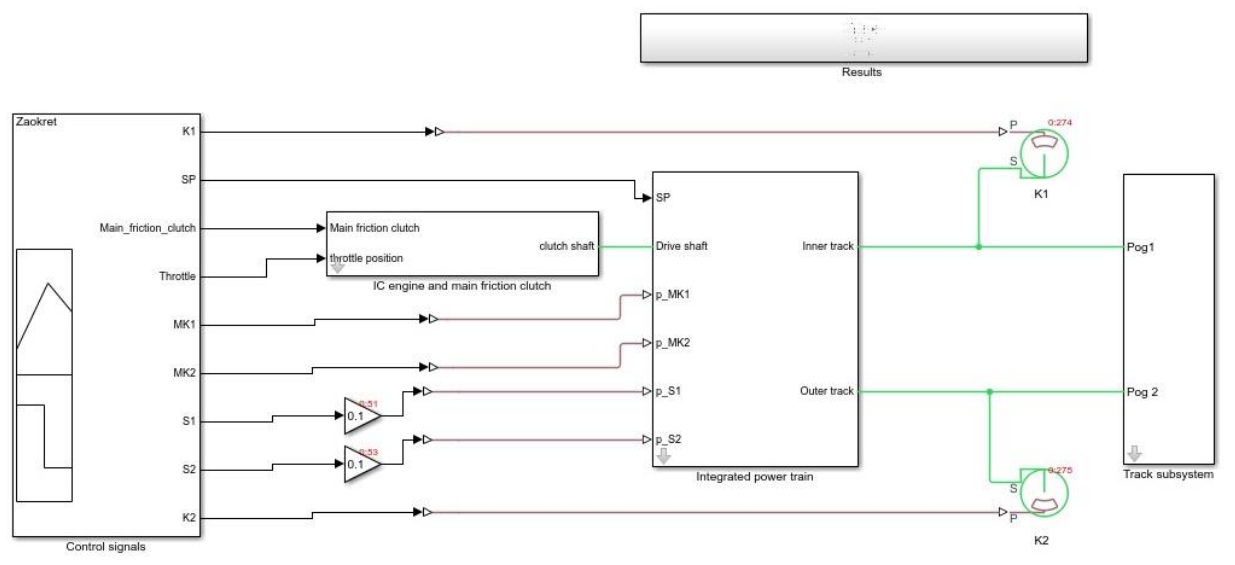

Figure 4 Vehicle simulation model

\subsection{IC engine and main friction clutch subsystem}

The IC engine with main friction clutch subsystem consists of engine block and main friction clutch block with activation command and lever system (Figure 5). This subsystem provides the drive power parameters (torque and angular velocity) and transfers them to the power train. The IC engine is conducted by the throttle position signal, and the clutch is engaged/disengaged by the activation force signal, both from the control signal block.

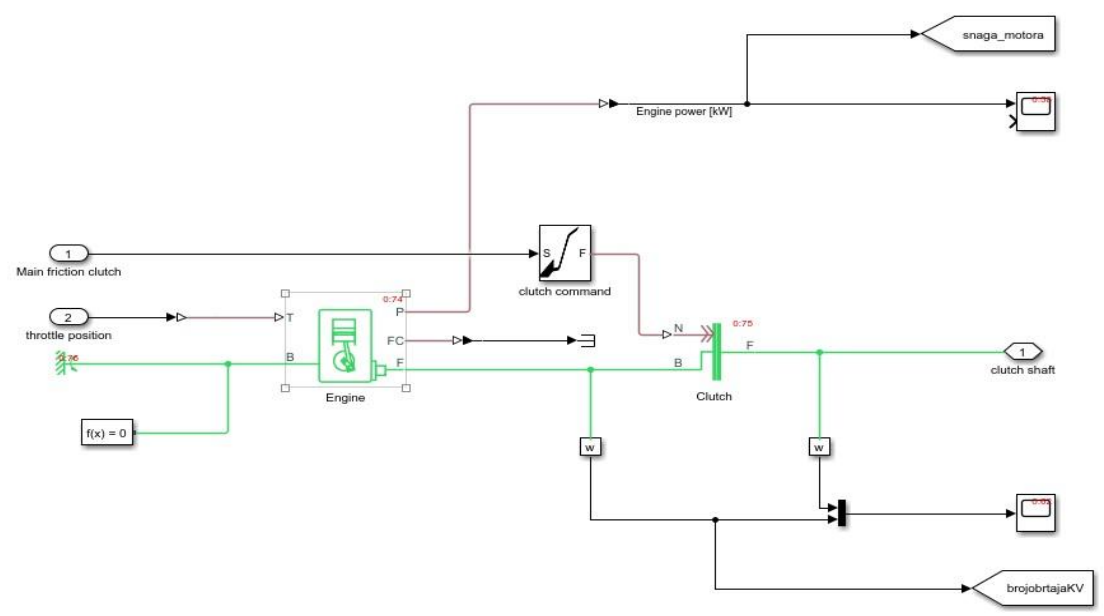

Figure 5 Engine and main friction clutch block

\subsection{Integrated power train subsystem}

Integrated power train subsystem consists of mechanical gearbox components and turning mechanism components (Figure 6) and has the role of transferring and altering torque and angular velocity, as well as enabling the turning process of the vehicle through the auxiliary drive. 


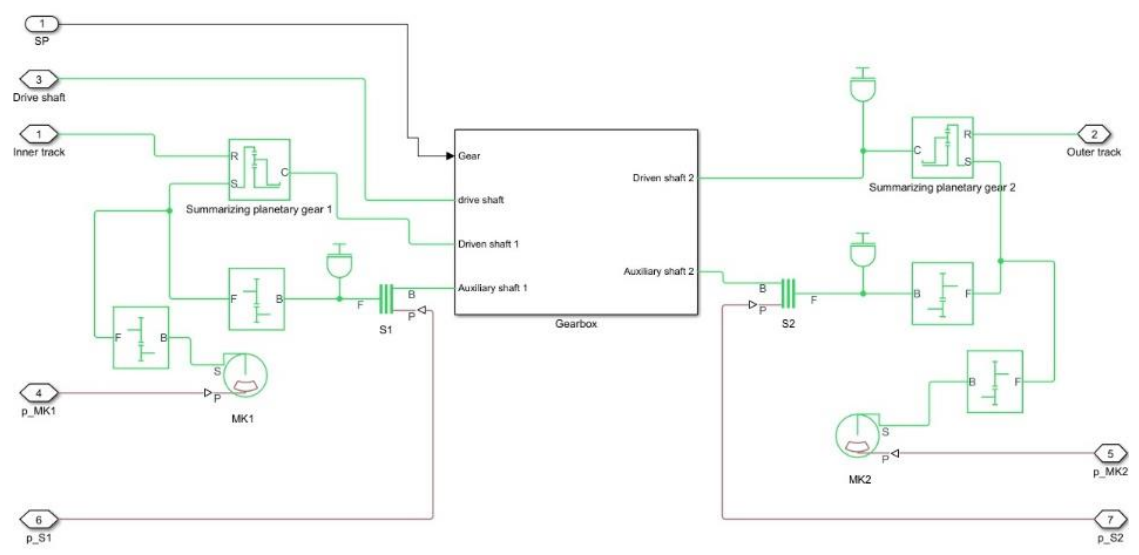

Figure 6 Integrated power train block

The mechanical gearbox (Figure 7) is driven by the main friction clutch shaft. It has five forward gears and one reverse gear, all of them engaged with synchronizers. The power is transferred from the drive shaft to the driven shaft via transfer shaft. The gear changing is achieved by sending gear request signal, from the control signal block, too a multi-position switch. The switch sends the activation signal to the gear actuators where the actuation force is generated and transferred to the corresponding synchronizers via lever system, thus activating the requested gear.

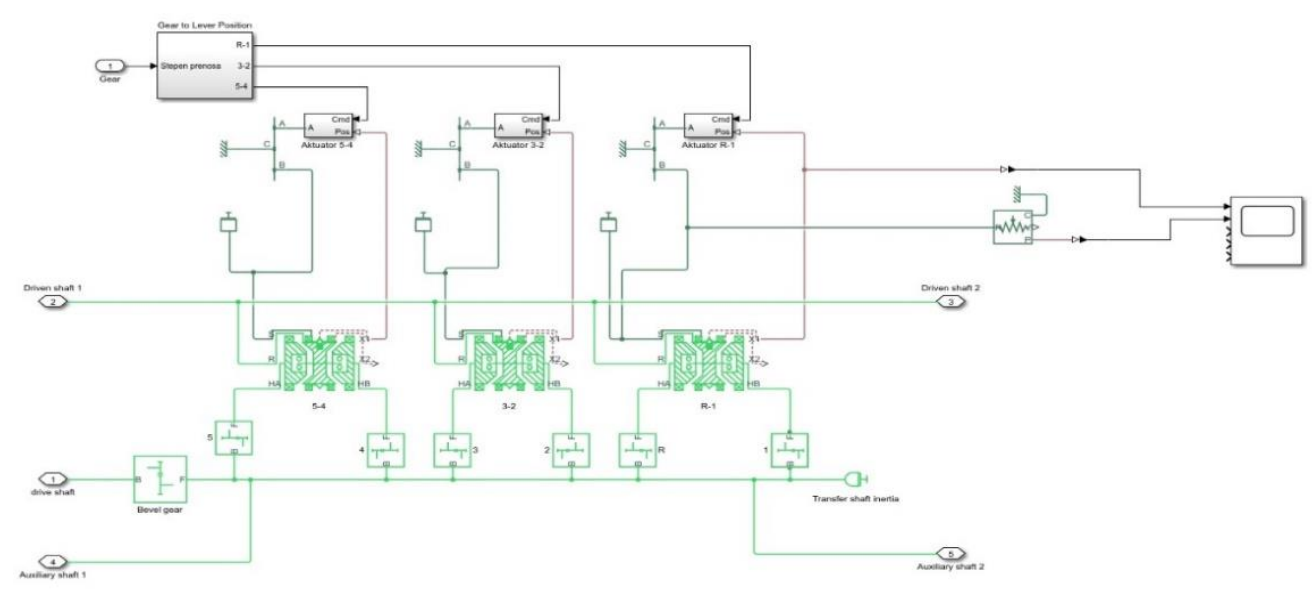

Figure 7 Mechanical gearbox block

The driven shaft has two exit points, for left and right track systems. The driven shaft transfers power to the planet carrier of the summarizing planetary gears. The transfer shaft of the gearbox is also the auxiliary drive shaft. When turning, the auxiliary drive shaft is connected to the sun gear of one of the summarizing planetary gears via friction clutches S1 or S2. When moving forward, the sun gear is braked by disc brakes MK1 or MK2 (Figure 6 ). The ring gear of both summarizing planetary gear sets are connected to the integrated power train exit shaft and transfer the drive power to the sprocket and track subsystem. 


\subsection{Sprocket and track subsystem}

Sprocket and track subsystem represents the components which come after the integrated power train in the kinematic chain, as well as the resisting forces on the tracks (Figure 8). It consists of the inner and outer (left and right) track subsystems, turning radius calculus subsystem and components for different measurement display.

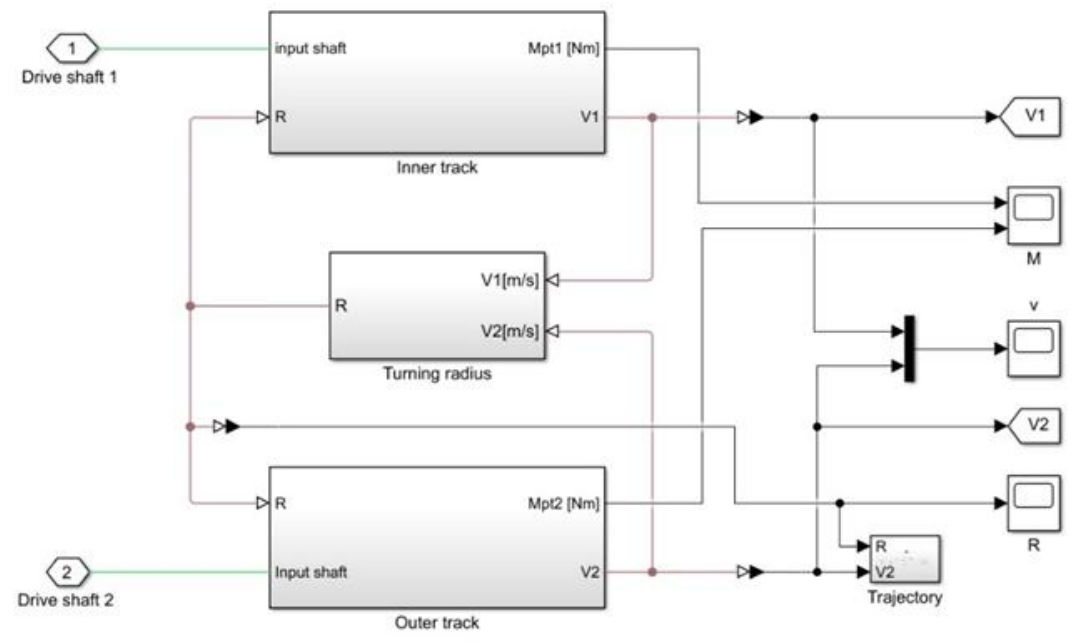

Figure 8 Sprocket and track subsystem

The inner and outer track subsystem consists of mechanical components representing the real elements of the power train, and the physical signals which simulate the moving resisting forces on tracks (Figure 9). These physical signals are connected to a torque source, thus becoming a real load on the mechanical power train components. The summarizing load on the mechanical components is measured and it represents the sprocket/drive wheel torque. By measuring the angular velocity of the mechanical components, we acquire the information about translational track velocity, which figures in the turning radius and turning resistance calculus.

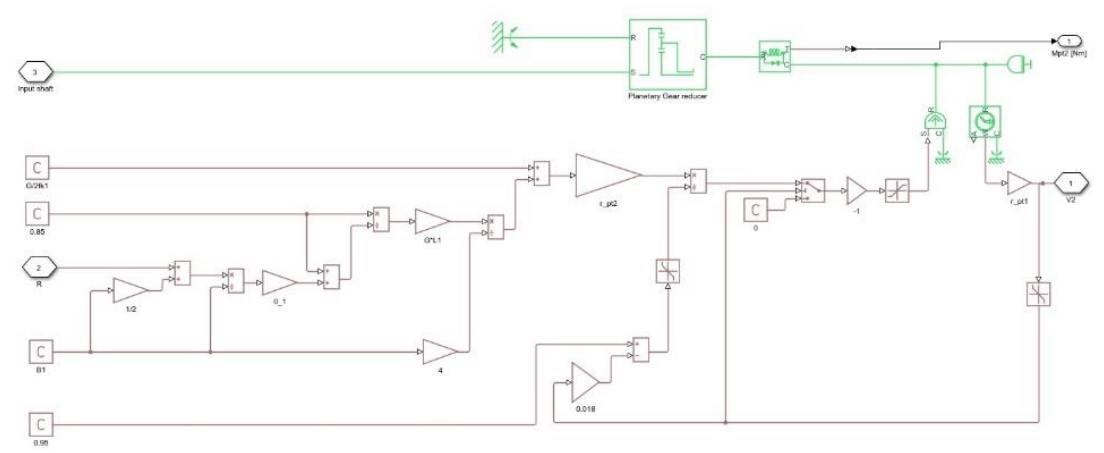

Figure 9 Track subsystem 


\subsection{Elecrtic auxiliary drive}

As mentioned, the main difference between the existing and modernized vehicle power train is in the auxiliary drive (Figure 10). The auxiliary drive of the modernized power train consists of two electric motors applied instead of friction clutches S1 and S2. The electric motors are represented with two asynchronous electric motor blocks labeled MG1 and MG2 (Figure 11). The electric motors have a mechanical connection with the sun gears of the summarizing planetary gear sets, electrical connection with the batteries and connections concerning the acquisition of measured values.

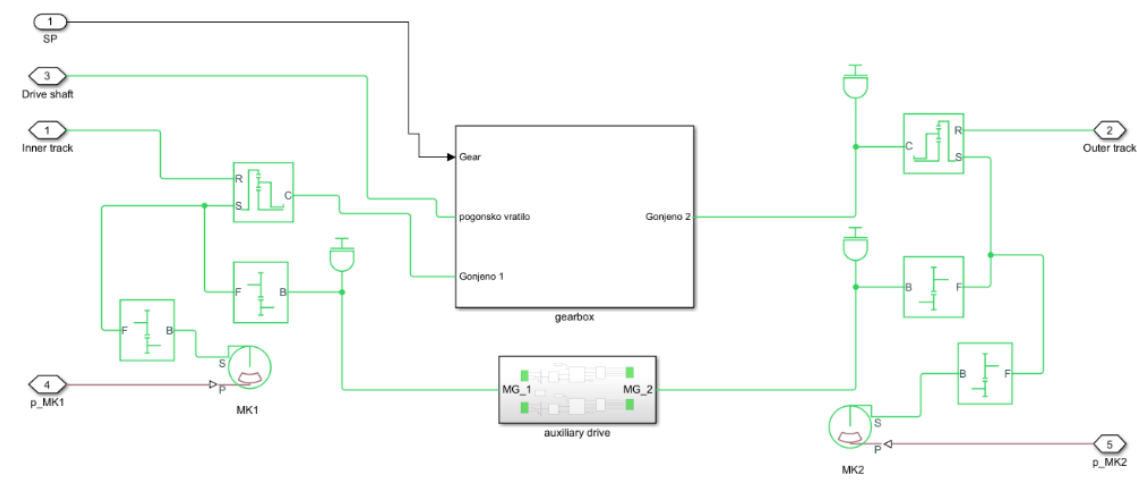

Figure 10 Electric integrated power train
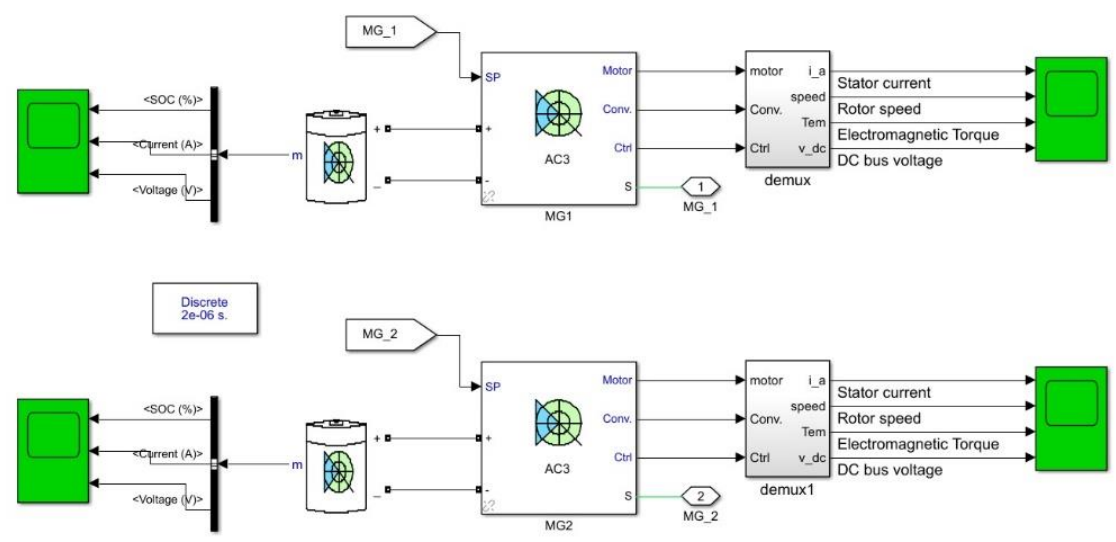

Figure 11 Electric auxiliary drive subsystem

The electric motors are controled with the signal from the control signal block. The signal represents the requested value for motor angular velocity (rpm). The motors are still in forward movement (except for the case when they are both working and driving the vehicle only with electric energy). When turning, the motor of the inner track speeds up the sun gear of the summarizing planetary gear set. Given the fact that the batteries give direct current, and the motors work on alternated current, the MG1 and MG2 motor blocks contain inverters and other necessery components for the DC/AC conversion. The battery model is based on experimental validation [5]. 


\section{SIMULATION MODEL ANALYSES}

To evaluate the quality of the turning mechanism hybridization, a simulation of the turning process is made, with the same conditions, for both mechanical and hybrid turning mechanisms. The simulation scenario implies the vehicle movement starting from the still state in first gear and turning with the parameters which will result with the same values of velocity and turning radius, at the end of the turning process. The analisys of the mechanical power train implies graduatelly deacivating Ko1 brake, followed by engaging the $\mathrm{S} 1$ friction clutch. As for the hybrid turning mechanism, the equivalent state would be engaging the inner track electric motor to the angular velocity coresponding the angular velocity of the auxiliary drive of the mechanical turning mechanism. Figure 12. shows the outer track velocity (v2), inner track velocity (v1) and center of mass velocity (v), where the values labeled MD refer to mechanical drive, while the ones labeled HD refer to hybrid drive. It is apparent that the inner track velocity change of the mechanical turning mechanism is faster than in the case of hybrid drive, which is a consequence of the incapability of precise slip regulation of friction elements. This happens in practice as well, which is why tracked vehicles with mechanical turning mechanisms can't achieve continuous turning. On the other hand, it is clear that the hybrid turning mechanism has a more mild and continuous velocity change.

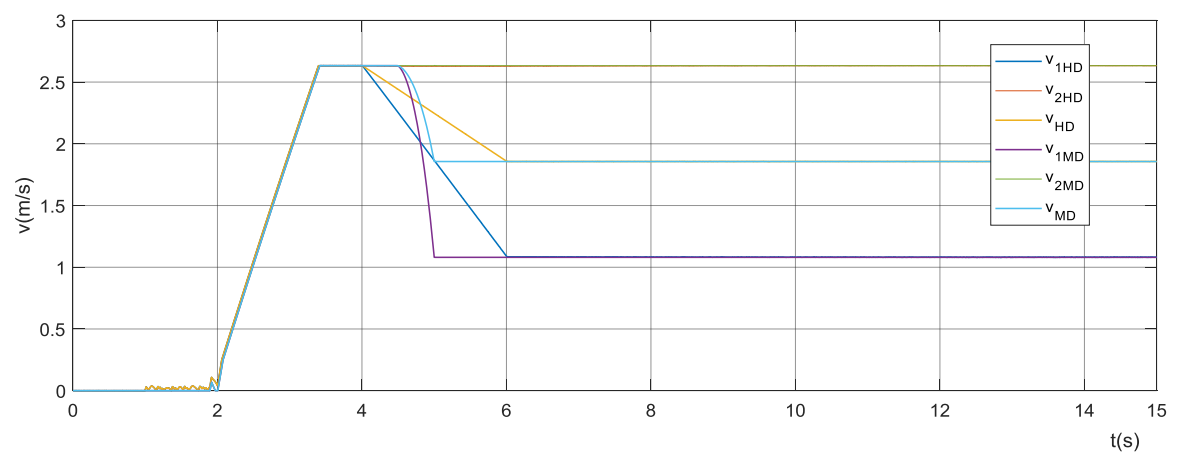

Figure 12 Track velocities during the turning process

Above mentioned is obvious in turning radius analysis as well, where we can observe that with the hybrid turning mechanism the requested turning radius is achieved continuous, unlike with the mechanical turning mechanism, where the requested turning radius is achived faster, but with greater dynamic loads on the power train elements.

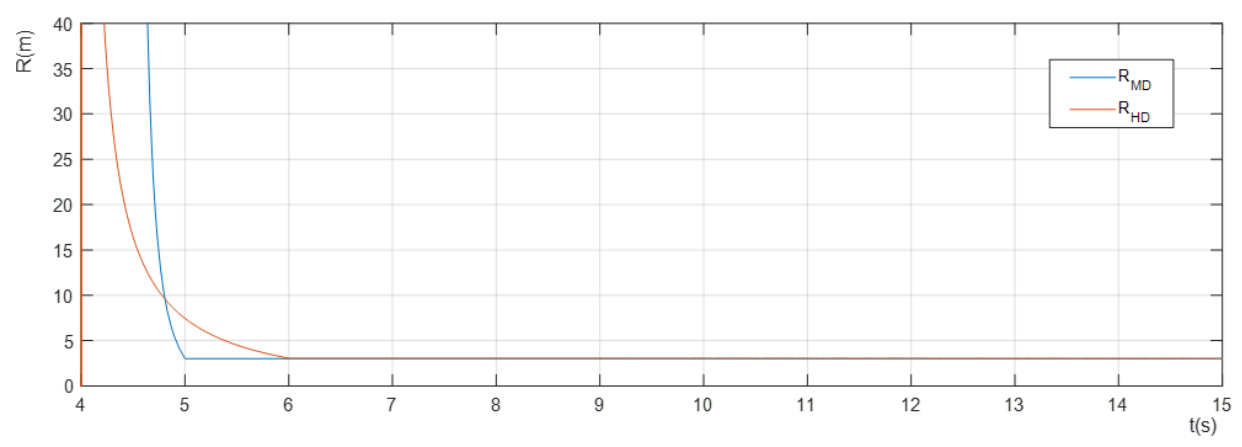

Figure 13 Turning radius change 
The power of the drive units during the turning process is shown in Figure 14. It is clear that, in stationary regimes, with both types of turning mechanisms, the total power of the power train is equivalent, which is expected concerning the fact that the turning process with mechanical turning mechanism is achieved without slipping losses of the friction elements. However, it is also obvious that during the turning process of the hybrid turning mechanism, significantly less power of the ICE engine (P_ICE) is being consumed for the turning process, which is important from the aspect of the vehicle performance improvement with this type of hybridization. It is important to state that the quality of the hybrid turning mechanism is shown at state of turning radius different than calculated turning radii, which is a most common state during the turning process, when it is expected that the total power of the power train is less than the requested drive unit power of the power train with the mechanical turning mechanism. Also, the hybrid turning mechanism can ensure any turning radius with a stable and requested value.

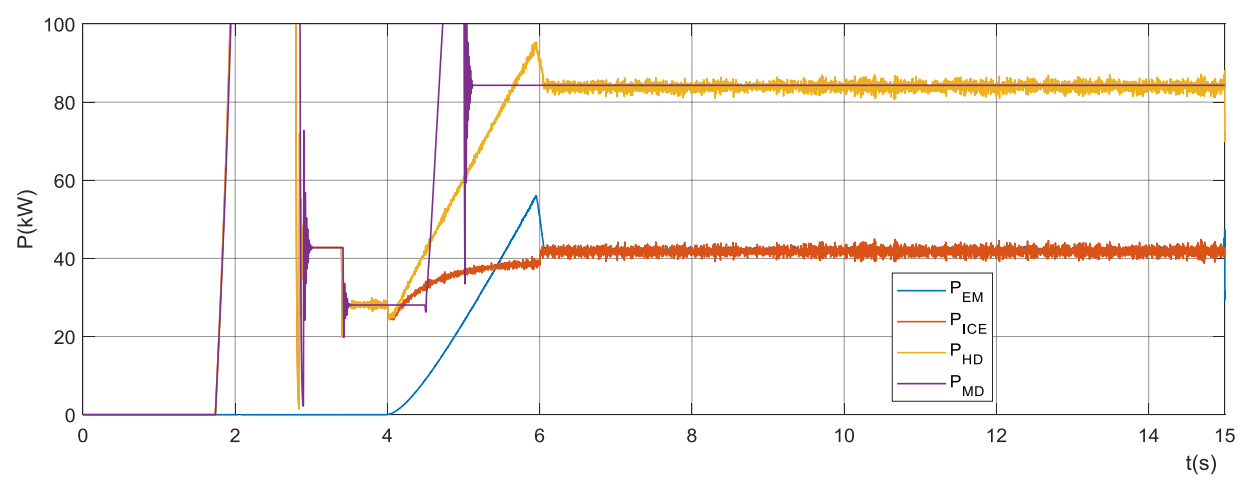

Figure 14 Power change of the drive units during turning process

\section{CONCLUSIONS}

The development of the electric drive technologies has given us the possibility to draw significant power parameters from compact and simple electric motors with reasonable energy consumption. Implementing these drives in tracked vehicles allows us to make noticeable improvements of the vehicle performance, energy consumption and manipulation. Most important power train improvements with hybrid turning mechanisms is ensuring continuous and stable turning process, with significantly less IC engine power consumed. The turning process is fully controlled and infinite number of turning radii, within a given range, can be achieved and maintained. Also, there is an aspect of energy generation by electric motors, in certain driving states, which were not considered in this paper. However, the drawbacks of these solutions should be considered as well. Power trains with electric motors require large storages of electric energy, which have to provide enough electric energy for turning processes in hard condition, repeatedly. These electric motors have variable efficiency, making them inefficient in certain regimes. There is a difficulty of physical placement and cooling of the electric components in the confined space such as the housing of the integrated power train of the considered track vehicle. On the other hand, power train with mechanical turning mechanism do not require batteries and other expensive electric components, but they draw a significant amount of IC engine power for turning, decreasing the vehicle performance parameters, turning process is mostly unstable and intermittent, with intensive loads on the friction and other power train 
elements. There are also noticeable inefficiencies in the turning mechanism from the friction elements slip losses, which are not especially shown in this paper, but have a negative impact on the vehicle turning process.

\section{REFERENCES}

[1] Sivakumar, P., Rajaseeli, R., Venkatesan, G., Viswanath, H., Selvathai, T.: "Configuration Study of Hybrid Electric Power Pack for Tracked Combat Vehicles", Defence Science Journal, 2017, Vol. 67, No. 4, pp. 354-359. Doi: 10.14429/dsj.67.11454.

[2] Ilijevski, Ž.: "A Hybrid-Electric Drive Concept for High Speed Tracked Vehicles", Proceedings of the 13th International ISTVS Conference, 2003, Munich, Germany.

[3] Bhatia, V.: "Hybrid tracked combat vehicle", 2015 IEEE International Transportation Electrification Conference (ITEC), Chennai, 27-29 August 2015, pp. 1-23. Doi: 10.1109/ITEC-INDIA.2015.7386862.

[4] Muždeka, S., Pantić, M., Arsenić, Ž.: "Vučne performanse zaokreta brzohodnih guseničnih vozila“, Međunarodni simpozijum (13) MVM, Kragujevac, 2004. (in Serbian).

[5] Tremblay, O., Dessaint, L.A.: "Experimental Validation of a Battery Dynamic Model for EV Applications“, World Electric Vehicle Journal, 2009, Vol. 3, Iss. 2, pp. 289298. Doi: $10.3390 /$ wevj3020289. 